\title{
RANCANGAN PROGRAM PEMBELAJARAN DARING DI PERGURUAN TINGGI: STUDI KASUS PADA MATA KULIAH KURIKULUM PEM- BELAJARAN DI UNIVERSITAS PENDIDIKAN INDONESIA
}

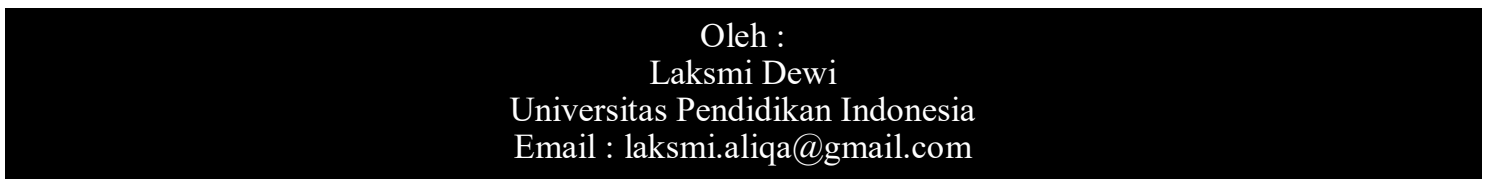

\begin{abstract}
This research aims to develop online learning program of Curriculum and Instruction Course to enhance effectiveness and efficiency which include tools and management of online learning, system of evaluation, and assessment of effectiveness and efficiency of online learning. The online learning program was conducted to facilitate the high number of classes that should be served. The research method used was design and development, where the program developed was in the form of prototype which was then tested in limited scale. The analysis of the problems revealed that students' competency was influenced by their low motivation because Curriculum and Instruction course was regarded as second level course. An online learning program was developed to enhance students' competency in studying Curriculum and Instruction course through several steps consisting of preparation/development, implementation, and evaluation using systemic approach.
\end{abstract}

Keywords: online learning, design and development, higher education institution

Abstrak. Penelitian ini bertujuan mengembangkan program pembelajaran daring pada Mata Kuliah Kurikulum dan Pembelajaran untuk mendukung efektivitas dan efisiensi pelaksanaan perkuliahan, mengembangkan perangkat dan tatakelola Pembelajaran Daring, dan mengembangkan sistem penilaian dan melakukan penilaian terhadap efektivitas dan efisiensi Pembelajaran Daring pada Mata Kuliah MKDK Kurikulum dan Pembelajaran yang efektif dan efisien. Hal ini didasarkan pada banyaknya kelas yang harus dilayani proses pembelajarannya. Metode penelitiannya menggunakan metode design dan pengembangan, yaitu metode dimana program yang dikembangkan baru berbentuk prototype yang kemudian dapat diujicobakan secara terbatas. Hasil dari analisis masalah pada penelitian ini adalah masih rendahnya penguasaan kompetensi belajar mahasiswa dipengaruhi oleh rendahnya motivasi belajar mahasiswa yang menyebutnya bahwa mata kuliah Kurikulum dan Pembelajaran dianggap sebagai kelompok mata kuliah level kedua. Kemudian melalui penelitian ini mengembangkan model pembelajaran daring meningkatkan kompetensi belajar mahasiswa, pada mata kuliah MKDP Kurikulum dan Pembelajaran. Program pembelajaran melalui tahapan persiapan/ pengembangan, pelaksanaan, dan evaluasi, dengan menggunakan pendekatan sistemik.

Kata Kunci: Pembelajaran daring, Perancangan dan Pengembangan, Perguruan Tinggi

\section{A. PENDAHULUAN}

Perkembangan yang terjadi di dunia pendidikan, khususnya di pendidikan tinggi berperan terhadap peningkatan kualitas lulusan yang harus mampu bersaing di era abad 21 ini. Kemampuan yang perlu dimiliki pada abad 21 ini berkaitan dengan kemampuan "life and career skills, learning and innovation skilss, and information, media and technology skills” (Partnership fo 21 Century Skills (2015). Saat ini dengan 
Persaingan yang begitu ketat menuntut perguruan tinggi untuk dapat menghasilkan lulusan yang memiliki kualitas kompetitif serta lulusan yang mampu bertahan hidup dalam menyelesaikan permasalahan-permasalahan yang dihadapi dalam kehidupannya. Perkembangan masyarakat yang begitu cepat perubahannya harus menjadi dasar dalam perubahan yang terjadi di dunia pendidikan tinggi (Gufron, 2007: 105106).

Berdasarkan perubahan yang terjadi pada sistem pendidikan tinggi di Indonesia, perguruan tinggi mantan Lembaga Pendidikan Tenaga Kependidikan (LPTK) terus berupaya melakukan pembaharuan di bidang pendidikan. Dengan wider mandate yang diberikan kepada LPTK menjadi universitas tentunya hal ini memberikan tantangan luar biasa bagi perguruan tinggi tersebut untuk dapat bersaing dengan perguruan tinggi lainnya. Untuk itu perlu dikembangkan berbagai inovasi, salah satunya dalam melaksanakan proses pembelajaran.

Sebagai perguruan tinggi yang memiliki latar belakang LPTK, Universitas Pendidikan Indonesia (UPI) tetap melaksanakan program perkuliahan kependidikan, dimana untuk semua mahasiswa yang berada di program studi kependidikan diberikan pembekalan sejumlah mata kuliah yang dapat meningkatkan kompetensi pedagogik. Menurut Peraturan Pemerintah No. 74 Tahun 2008 tentang Guru yang menjelaskan bahwa kompetensi pedagogic yaitu kemampuan mengelola pembelajaran yang meliputi pemahamaan wawasan pendidikan, pemahaman terhadap peserta didik, mengembangkan kurikulum atau silabus, merancang pembelajaran, melaksanakan pembelajaran, memanfaatkan teknologi pembelajaran, melakukan evaluasi belajar, serta mampu mengembangkan potensi peserta didik agar dapat diaktualisasikan dalam kehidupannya.

$$
\text { Pada kenyataannya dalam }
$$

melaksanakan proses pembelajaran untuk meningkatkan kemampuan pedagogik tersebut, mahasiswa masih memiliki motivasi belajar yang rendah serta kurangnya kemampuan belajar mandiri pada diri mahasiswa. Salah satu mata kuliah untuk mendukung pencapaian kompetensi pedagogik tersebut adalah mata kuliah Kurikulum dan Pembelajaran. Hasil penelitian Alinawati, dkk (2009: 45) menunjukkan motivasi belajar mahasiswa pada mata kuliah MKDP khususnya Kurikulum dan Pembelajaran masih rendah. Hal ini berdampak pada perolehan hasil belajar mahasiswa yang belum memuaskan". Selain itu secara kuantitas dosen yang 
mengajar mata kuliah tersebut tidak memiliki rasio yang mencukupi dengan jumlah mahasiswa yang harus dilayani. Jumlah mahasiswa setiap tahunnya bertambah signifikan sementara penambahan dosen kurtek setiap tahunnya sangat minim, bahkan tidak ada penambahan, dengan demikian terjadi beban kerja mengajar yang berlebihan untuk dosen Kurtek

Penciptaan proses pembelajaran yang efektif terus dikembangkan untuk meningkatkan motivasi dan hasil belajar mahasiswa. Untuk itu diarahkan pada proses pembelajaran yang dapat meningkatkan keterlibatan mahasiswa lebih aktif, lebih mandiri, yang didorong oleh motif untuk peningkatan puangasaan kompetensi untuk mengatasi suatu masalah, dan dibangun dengan bekal pengetahuan atau kompetensi yang dimiliki (Haris Mujiman, 2005 dalam Dhesiana (2009: 2). Dengan demikian, diperlukan satu terobosan untuk melakukan pembelajaran yang efektif dan efisien dengan jumlah dosen yang terbatas dan tetap dapat melayani mahasiswa yang tersebar di lingkungan UPI. Salah satu cara yang dapat dilakukan diantaranya menerapkan model pembelajaran yang menekankan pada sistem pembelajaran jarak jauh, salah satunya dengan pembelajaran daring (online learning).

Berdasarkan analisis tersebut, maka perkuliahan daring memiliki potensi yang besar menjadi salah satu alternatif pemecahan masalah dalam upaya meningkatkan pemahaman calon guru pada kompetensi pedagogik. Untuk mengatasi permasalahan perkuliahan MKDK Kurikulum dan pembelajaran, dalam kondisi jumlah dosen yang terbatas, namun dapat tetap melayani pembelajaran secara intensif. Hal ini sejalan dengan tuntutan pembelajaran abad 21 yang lebih menuntut belajar secara mandiri. Menciptakan lingkungan belajar melalui internet harus didukung berbagai sumber belajar sehingga dapat mewujudkan lingkungan belajar mandiri yang kondusif, dimana lingkungan belajar mengarah kepada pengembangan fasilitas yang memberikan kebebasan bagi mahasiswa untuk dapat memproses kegiatan pembelajaran dengan menyediakan dukungan yang fleksibel, dapat diakses, dan selalu ada ketika dibutuhkan dan juga adanya dukungan prospektif untuk mahasiswa (Moisey \& Hughes, 2008)

Pembelajaran daring (online learning) merupakan model pembelajaran yang berbasis ICT. Daya dukung program ini adalah fasilitas ICT berupa web LMS, program monitoring, modular dan 
suplemen dalam bentuk multimedia. Penelitian yang dilakukan Zakaria (2007: 13) menyatakan bahwa dengan menggunakan e-learning sebagai bagian dari proses pembelajaran merupakan suatu upaya penting dalam membantu peserta didik mendapatkan materi pembelajaran secara dini, melalui $e$ learning penguasaan kompetensi mahasiswa pada setiap substansi pembelajaran dapat terus meningkat, jika disertai dengan strategi pembelajaran yang tepat, media pembelajaran yang mampu mengakomodasi berbagai keperluan mendasar dalam proses pembelajaran.

Telah banyak penelitian yang dilakukan terkait dengan pengembangan web untuk kepentingan pembelajaran. Beberapa hasil penelitian menunjukkan bahwa pembelajaran dengan menggunakan media daring (online) berbasis web memberikan pengaruh yang positif dalam peningkatan proses pembelajaran. Pengaruh positif ini bukan hanya diperoleh siswa, tetapi juga kepada guru (Baisa, 2010; Liu, 2009; Hussin, Bunyarit \& Hussein: 2009; Ng Wan, 2008; Prunchnicki, at all: 2005; Wijekumar, 2005; Hoogveld, at all: 2001; Oliver, 2000; McNulty, John A; Dauzvardis, Michael F; Espiritu, Baltazar: 2000). Menurut beberapa hasil penelitian tersebut disampaikan bahwa melalui pembelajaran daring berbasis web siswa merasa puas, karena materi yang disampaikan telah diorganisasikan dengan baik (Hussin, Bunyarit \& Hussein: 2009). Lebih lanjut memaparkan bahwa melalui web pembelajaran menjadi lebih fleksibel dan membantu mengakomodasi berbagai kebutuhan gaya belajar serta menumbuhkan rasa percaya dalam belajar (Oliver 2000; Prunchnicki, at all: 2005). Melalui pembelajaran web juga dapat membantu peserta didik melakukan pemecahan masalah-masalah yang diangkat dalam proses pembelajaran. melalui pembelajaran daring melalui web juga dapat mempermudah proses evaluasi, karena menjadi lebih efektif, efisien, dan objektif, baik secara individu maupun secara berkelompok (McNulty, John A; Dauzvardis, Michael F; Espiritu, Baltazar: 2000).

Berdasarkan hasil-hasil penelitian tersebut, jelas memperkuat perlunya dikembangkan berbagai sarana pembelajaran daring yang dapat mendukung terhadap peningkatan kualitas pembelajaran. Perbedaan hasil-hasil penelitian yang telah diungkapkan sebelumnya dengan penelitian ini adalah sasarannya adalah siswa di level perguruan tinggi dan merupakan calon guru. Fokus penelitiannya berada pada peningkatan 
kompetensi pada aspek pedagogik. Penelitian ini akan memfokuskan pada proses desain pengembangannya, sehingga akan tergambarkan bagaimana proses pengembangan web yang dapat meningkatkan kompetensi pedagogik.

Penelitian ini bertujuan mengidentifikasi kondisi awal pembelajaran dan merancang program pembelajaran daring pada Mata Kuliah Kurikulum dan Pembelajaran untuk mendukung efektivitas dan efisiensi pelaksanaan perkuliahan. Dampak yang diharapkan dari pengembangan ini adalah meningkatknya mutu perkuliahan $\mathrm{Ku}$ rikulum dan Pembelajaran yang disertai dengan meningkatnya kompetensi pedagogik yang dimiliki mahasiswa program kependidikan, khususnya kompetensi dalam bidang pengembangan kurikulum dan pembelajaran

Metode penelitian yang digunakan adalah menggunakan metode design dan pengembangan (design and development), yaitu metode penelitian yang sistematis dalam merancang, mengembangkan, dan mengevaluasi suatu proses atau produk untuk mengembangkan suatu inovasi dalam pembelajaran. Langkah penelitian meliputi 1) identifikasi kondisi awal pembelajaran, 2) merancang dan mengembangan model, 3 ) menguji model, dan mendesiminasikan model. Pada penelitian ini tahap yang dilakukan meliputi tahap identifikasi kondisi awal pembelajaran, dan merancang model pembelajaran daring. Kegiatan ini dilakukan pada tahun 2016. Tahap keempat dan kelima baru akan dilakukan pada penelitian berikutnya.

Dalam mengembangkan produk pembelajaran daring ini melibatkan para ahli yang terdiri dari ahli konten, yaitu ahli yang berkaitan dengan bidang keilmuan kurikulum, dan ahli teknis, yaitu ahli yang mengembangkan program pembelajaran daring. Kedua tim ini berkolaborasi untuk menghasilkan program yang dianggap baik dan efektif untuk dapat meningkatkan motivasi dan hasil belajar mahasiswa.

Berdasarkan prosedur penelitian, maka langkah-langkah yang dilakukan pada penelitian ini adalah: 1) Mengidentifikasi masalah. Kegiatan ini dilakukan dengan melakukan studi dokumentasi berbagai hasil penelitian yang telah dilakukan oleh orang lain, juga mengidentifikasi hasil belajar mahasiswa yaitu dengan melihat perolehan nilai UAS. Juga melakukan diskusi dengan rekan sejawat untuk memberikan masukanmasukan terkait program yang akan dikembangkan; 2) Merumuskan masalah. Dari hasil identifikasi masalah kemudian merumuskan atau memfokuskan pada 
salah satu masalah. 3) Merancang dan mengembangkan model/prototype dari program pembelajaran daring.

\section{A. HASIL DAN PEMBAHASAN}

\section{Identifikasi Kondisi Awal Pem- belajaran}

Identifikasi masalah dilakukan dengan menyebarkan kuisioner dan studi dokumentasi tentang kondisi pelaksanaan pembelajaran berdasarkan persepsi mahasiswa. Melalui kuesioner yang disebarkan kepada mahasiswa tentang pendapat pentingnya mata kuliah MKDP Kurikulum dan Pembelajaran. Menurut mahasiswa, mata kuliah MKDP Kurikulum dan Pembelajaran ini merupakan mata kuliah yang cukup penting, karena mata kuliah ini merupakan mata kuliah yang dapat memberikan wawasan dan keahlian berkaitan dengan penguasaan salah satu kompetensi pedagogik. Dengan memahami kurikulum dan pembelajaran, mahasiswa diharapkan dapat menguasai konsep dan implementasi kurikulum di sekolah.

Proses pembelajaran yang dilaksanakan dosen sudah sesuai dengan peraturan yang ditetapkan oleh Universitas. Kebijakan yang diberlakukan adalah proses pembelajaran harus berlangsung sebanyak 16 (enam belas) pertemuan. Metode pembelajaran yang digunakan pada mata kuliah Kurikulum dan Pembelajaran, menurut mahasiswa, kurang bervariasi. Metode pembelajaran yang digunakan cenderung monoton, seperti metode ceramah, metode tanya jawab, dan metode diskusi. Walaupun demikian, proses pembelajaran berjalan dengan baik karena mahasiswa dapat terlibat secara aktif dalam proses pembelajaran. Antusiasme mahasiswa selama proses pembelajaran berlangsung cenderung tidak stabil, tergantung dari semangat mahasiswa. Menurut mahasiswa antusiasme selama perkuliahan berlangsung dipengaruhi juga oleh penggunaan metode pembelajaran yang kurang variatif, sehingga mahasiswa sering merasa bosan. Namun dari sisi keaktifan, mahasiswa sudah cukup aktif terlibat dalam proses diskusi dan tanya jawab.

Seyogyanya ada beberapa kriteria yang dapat digunakan dalam memilih strategi pembelajaran. Kriteria tersebut harus berorientasi pada tujuan pembelajaran, pemilihan teknik pembelajaran yang sesuai dengan keterampilan yang diharapkan, dan penggunaan media seefektif mungkin yang dapat memberikan rangsangan pada indera peserta didik (Mager, 1977 dalam Uno, 2010:8). Penggunaan metode pembelajaran oleh dosen tentunya harus sesuai dengan materi yang akan disampaikan agar interaksi 
yang terjadi menjadi efektif. Print (1993: 66) menjelaskan terdapat dua alasan mendasar pentingnya penggunaan metode pembelajaran, yaitu kondisi peserta didik yang tidak selalu sama dan tidak adanya metode pembelajaran yang dapat diterapkan di setiap situasi. Metode pembelajaran yang digunakan cenderung monoton, tidak ada upaya penggunaan metode pembelajaran yang dapat meningkatkan kompetensi dan kemandirian belajar mahasiswa.

Media pembelajaran dan sumber belajar yang digunakan pada mata kuliah Kurikulum dan Pembelajaran ini adalah media presentasi powerpoint dengan menggunakan infokus. Media ini digunakan karena sudah tersedia di dalam kelas, sehingga memudahkan dosen dalam menyampaikan materi. Hal ini pun memberikan kesempatan yang sama kepada mahasiswa saat harus menyampaikan materi diskusi. Proses perkuliahan MKDP Kurikulum dan Pembelajaran masih menggunakan sumber belajar yang belum beragam. Bahkan ada kecenderungan mahasiswa hanya tergantung pada satu buku sumber saja saat membuat suatu makalah. Pentingnya pemanfaatan beragam media dan sumber belajar dalam perkuliahan dapat mendukung peningkatan mutu pembelajaran juga dapat mendukung meningkatkan pencapaian hasil belajar sesuai dengan yang diharapkan (Smaldino, Lowther \& Russel, 2007).

Evaluasi pembelajaran secara umum sesuai dengan pedoman akademik yang telah dikeluarkan oleh universitas. Evaluasi pembelajaran dilaksanakan Ujian Tengah Semester (UTS) dan Ujian Akhir Semester (UAS). Selain itu juga penilaian mahasiswa didasarkan pada tugas-tugas dan aktivitas mahasiswa selama perkuliahan berlangsung. Evaluasi pada dasarnya adalah suatu proses menentukan nilai dari suatu obyek atau peristiwa dalam konteks situasi tertentu (Sudjana, 1985 ; Sukmadinata, 2001). Pelaksanaan evaluasi yang dilakukan oleh dosen lebih banyak berorientasi pada penguasaan kognitif, sedangkan untuk mengevaluasi afektif dan psikomotor masih belum optimal dilakukan. Tujuan dari proses evaluasi adalah untuk mengetahui sejauh mana efektivitas proses pembelajaran dan juga untuk mengukur keberhasilan pencapaian tujuan pembelajaran yang telah ditetapkan. Masih rendahnya penilaian hasil belajar secara mandiri, masih dirasa belum dilakukan oleh mahasiswa. Sehingga belum ada relf reminder

Kesulitan-kesulitan yang dihadapi mahasiswa selama mengikuti perkuliahan Kurikulum dan Pembelajaran lebih 
banyak berkaitan dengan penguasaan konsep materi yang terlalu teoritis yang tidak diimbangi dengan kondisi nyata. Selain itu, kesulitan yang dihadapi juga berkaitan dengan penyediaan sumber belajar. Mahasiswa terkadang memiliki keterbatasan dalam memiliki sumber rujukan yang berakibat pada keterbatasan pengerjaan tugas. Saat mengerjakan karya ilmiah yang berkaitan dengan materi perkuliahan, mahasiswa seperti tidak memiliki bahan sumber rujukan karena bahan yang digunakan sangat terbatas.

Harapan mahasiswa dalam perkuliahan Kurikulum dan Pembelajaran berkaitan dengan proses pelaksanaan pembelajaran yaitu sebaiknya dosen menggunakan metode dan media pembelajaran yang lebih bervariatif, sehingga bisa meningkatkan motivasi belajar. Selain itu juga mahasiswa diberikan kesempatan terllibat dalam proses pembelajaran yang lebih aktif.

Peningkatan kompetensi belajar mahasiswa dapat ditingkatkan melalui proses pembelajaran yang efektif dengan menggunakan berbagai sumber daya pembelajaran yang tersedia di lingkungan kampus. Dengan menggunakan berbagai macam sumber belajar dalam proses pembelajaran dapat memberikan pengaruh positif dalam perolehan hasil belajar belajar mahasiswa, dengan melakukan inovasi dalam pembelajaran khususnya dengan menggunakan perangkat-perangkat pembelajaran berupa komputer dapat memberikan pengaruh terhadap proses pembelajaran, dan akan berdampak pada peningkatan hasil belajar peserta $\operatorname{didik}($ Zakaria, 2007; Hasbullah, 2009; Lee, dkk,2002).

Berkaitan dengan permasalahan yang disampaikan, melalui penelitian ini mencoba mengembangkan model pembelajaran daring meningkatkan kompetensi belajar mahasiswa, pada mata kuliah MKDP Kurikulum dan Pembelajaran. Melalui pembelajaran daring diharapkan dapat membantu mahasiswa agar dapat belajar dan mengakses bahan belajar dimanapun dan kapan pun. Dengan adanya pembelajaran yang bersifat online. Hal ini diharapkan juga dapat meningkatkan kemandirian belajar mahasiswa.

\section{Merancang dan mengembangkan model/prototype dari program pembelajaran daring}

Pada kegiatan merancang dan mengembangan program pembelajaran daring meliputi persiapan, pelaksanaan, dan evaluasi, secara rinci dapat dilihat pada tabel sebagai berikut: 
Tabel 1.1 Kegiatan Perancangan dan Pengembangan Program Pembelajaran Daring

\begin{tabular}{|l|l|}
\hline No & Kegiatan \\
\hline A & Tahap Persiapan \\
\hline & Analisis kebutuhan \\
\hline 1 & Perancangan model sistem pembelajaran daring \\
\hline 2 & Pengembangan perangkat pendukung model sistem pembelajaran daring \\
\hline 3 & Pembuatan pedoman (manual model) sistem pembelajaran daring \\
\hline B & Tahap Pelaksanaan \\
\hline 1 & Pengintegrasian model sistem pembelajaran daring dengan SPOT LMS \\
\hline 2 & $\begin{array}{l}\text { Penyelenggaraan perkuliahan Mata Kuliah Kurikulum dan Pembelajaran dengan } \\
\text { menggunakan model sistem pembelajaran daring di berbagai prodi }\end{array}$ \\
\hline C & Tahap Evaluasi dan Pelaporan \\
\hline 1 & Evaluasi penyelenggaraan sistem perkuliahan dengan pembelajaran daring (evaluasi proses) \\
\hline 2 & Evaluasi terhadap perangkat pendukung pembelajaran daring (evaluasi produk) \\
\hline 3 & Evaluasi hasil belajar mahasiswa yang menggunakan pembelajaran daring \\
\hline 4 & Pelaporan Kegiatan Pengembangan \\
\hline
\end{tabular}

\section{Tahap Persiapan}

Aktivitas pengembangan dilakukan melalui tiga tahapan yaitu analisis kebutuhan, perancangan produk, serta pengembangan produk.

Analisis kebutuhan dilakukan dengan merumuskan berbagai aspek kebutuhan yang diperlukan dalam proses perancangan dan pengembangan kuliah daring ini. Proses analisis dilakukan oleh tim dosen MKDK Kurikulum dan Pembelajaran dan memutuskan bahwa untuk tahap perancangan dan pengembangan dibutuhkan pembentukan tim khusus untuk mendukung proses pengembangan ini. Tim ini terdiri dari tim pengembang konten yang terdiri dari dosen-dosen yang ditunjuk untuk mengembangkan strategi dan isi materi pembelajaran, serta tim teknis media yang akan bekerja untuk merancang dan mengembangkan bentuk sajian dan interaksi terhadap materi tersebut. Analisis kebutuhan melalui dua tahapan kegitan yaitu perumusan tim yang dilakukan oleh tim inti pengembang mata kuliah daring dan kemudian kegiatan analisis kebutuhan yang dilakukan oleh seluruh anggota tim.

Proses perancangan dilakukan dengan melibatkan seluruh tim. Proses ini dilakukan melalui tahap diskusi untuk menentukan pola penyampaian materi termasuk teknik dan metode yang akan digunakan, pemilihan aktifitas termasuk diantaranya topic diskusi yang akan dibahas, serta perencanaan delivery proses dari materi tersebut. Proses perancangan tersebut dikemas melalui dua kegiatan 
utama yaitu, workshop kuliah daring kelas terbuka serta finalisasi desain model kelas daring terbuka MKDK Kurikulum dan Pembelajaran.

Pengembangan produk yang berupa kelas daring terbuka dilakukan melalui beberapa tahap. Tahap yang pertama adalah forming perumusan materi yang akan disampaiakan, kemudian tahap yang kedua yaitu tahap extention adalah proses melengkapi media serta unsurunsur pendukung kelas daring terbuka, serta yang terakhir yaitu tahap ketiga adalah proses attachment yaitu proses peletakan atau penempatan semua unsur ke dalam situs yang akan digunakan sebagai wadah untuk kelas daring terbuka. Hasil akhir dari proses pengembangan produk adalah adanya purwarupa (prototype) dari kelas daring terbuka MKDK Kurikulum dan pembelajaran. Tujuan dengan adanya prototype ini diharapkan dapat menjadi model yang memberikan gambaran dalam pelaksanaan perkuliahan MKDK kurpem secara daring melalui kelas terbuka yang akan diselenggarakan secara utuh.

Dari hasil analisa diperoleh luaran perancangan dan pengembangan dalam bentuk Struktur Tim Kerja Pengembangan Kuliah Daring MKDK Kurikulum dan Pembelajaran yang terdiri dari tim pengembang konten dan tim teknis. Setelah tim dibentuk kemudian melakukan diskusi untuk menentukan desain pesan yang akan disajikan pada tampilan pembelajaran daring.

Desain penyajian kelas terbuka mata kuliah Kurikulum dan Pembelajaran dirumuskan memiliki beberapa unsur yang melengkapi aspek teknis dari sajian dan interaksi pada mata kuliah ini. Berikut adalah gambaran umum sajian kelas daring terbuka MKDK Kurikulum dan Pembelajaran.

Tabel 1.2 Desain program pembelajaran daring

\begin{tabular}{|l|l|}
\hline ZPERTEMUAN & Berisi judul setiap pertemuan \\
\hline BANNER & Banner tentang sesi yang akan berjalan \\
\hline TEKS & $\begin{array}{r}\text { Merupakan materi ringkas yang disajikan, berisi: } \\
\text { Sajian materi } \\
\text { Link/tautan terkait }\end{array}$ \\
\hline BAHAN AJAR & Berupa file Powerpoint (di PDF-kan atau di Autoshow-kan) \\
\hline LATIHAN & Berupa instruksi latihan untuk menambah dan memperkuat wawasan materi \\
\hline TOPIK DISKUSI & $\begin{array}{l}\text { Forum diskusi yang diberikan topic-topik terkait dengan materi yang akan } \\
\text { disampaikan }\end{array}$ \\
\hline EVALUASI* & Tes formatif pada setiap sesi (bias berupa pilihan ganda/essay/assignment) \\
\hline
\end{tabular}


Selanjutnya dari rancangan tersebut kemudian direalisasikan dalam bentuk pengembangan Kelas Terbuka dari MKDK Kurikulum dan Pembelajaran. Luaran dari proses pengembangan adalah tebentuknya prototype kelas daring terbuka untuk MKDK kurikulum dan pem- belajaran yang dapat memfasilitasi proses belajar secara efektif dan efisien. Berikut ini adalah tampilan dari prototype yang telah dirancang untuk memfasilitasi proses implementasi ujicoba kelas daring terbuka ini.

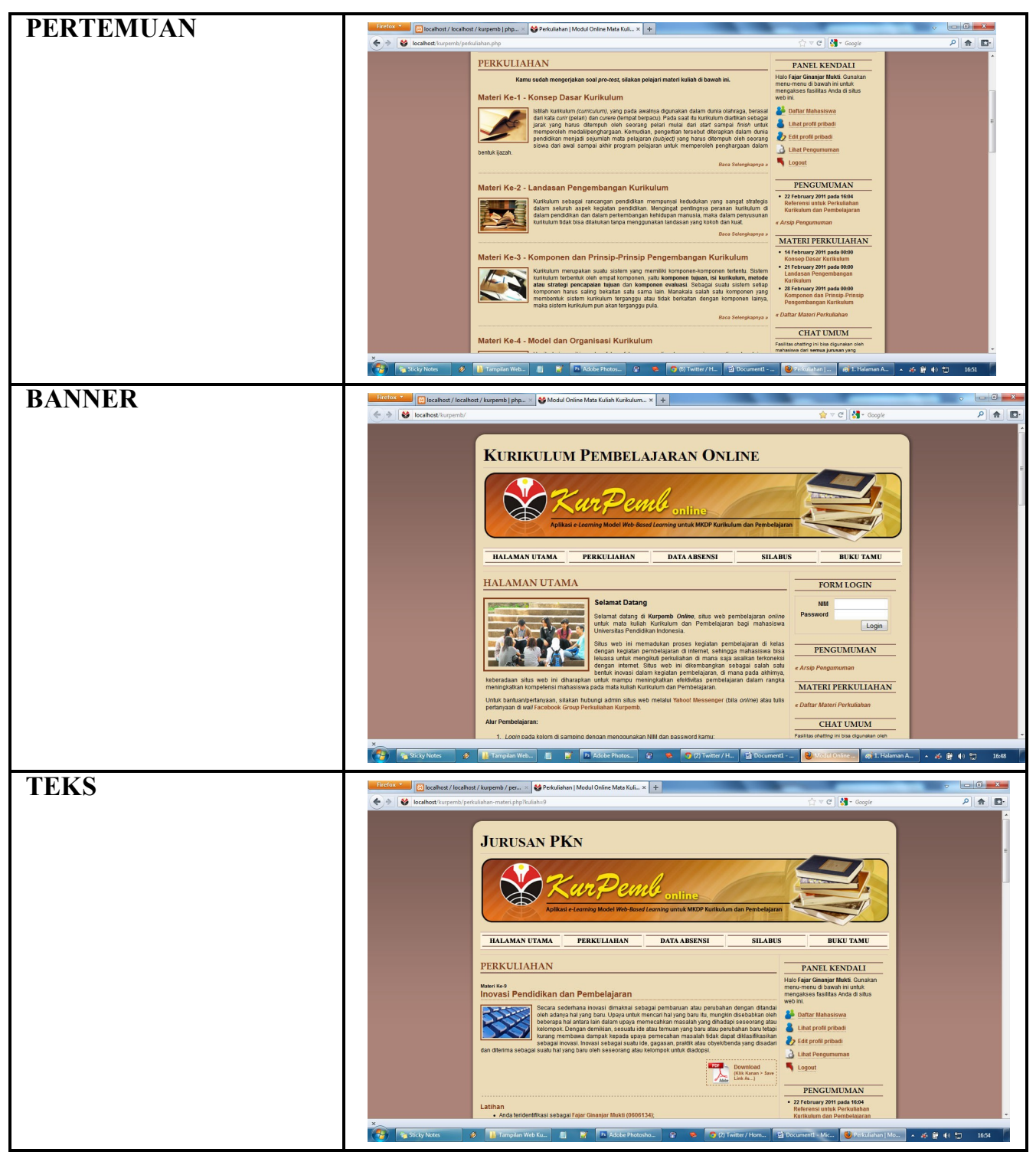

215 Rancangan Program Pembelajaran Daring Di Perguruan Tinggi: Studi Kasus Pada Mata Kuliah Kurikulum Pembelajaran Di Universitas Pendidikan Indonesia 
Edutech, Tahun 16, Vol.16, No.2, Juni 2017

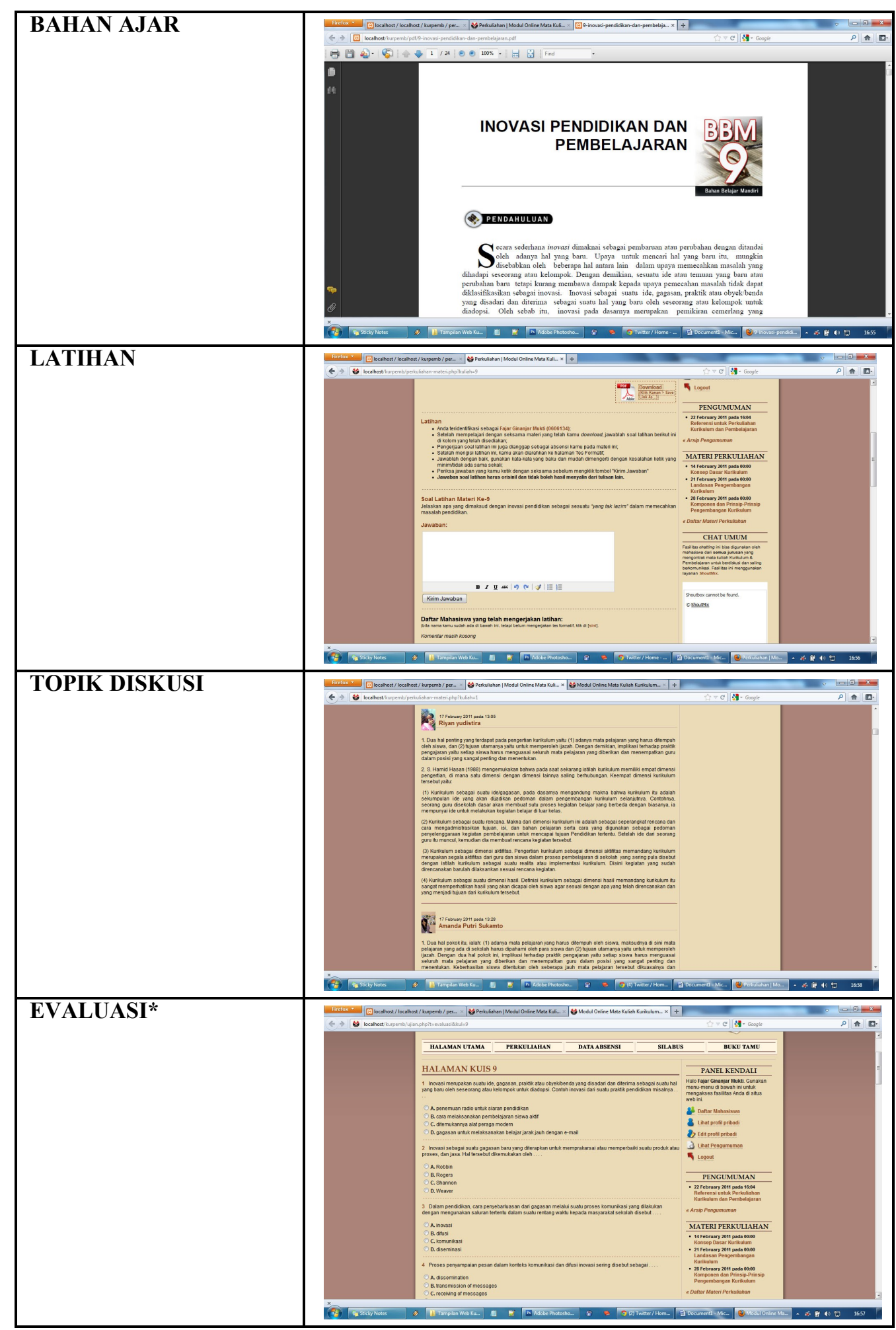

Gambar 1.1 Tampilan Rancangan Pembelajaran Daring MKDK Kurikulum dan Pembelajaran

216 Rancangan Program Pembelajaran Daring Di Perguruan Tinggi: Studi Kasus Pada Mata Kuliah Kurikulum Pembelajaran Di Universitas Pendidikan Indonesia 
Pengembangan program pembelajaran daring sebaiknya mengacu pada pengembangan pembelajaran dengan menggunakan pendekatan system. Tujuannya adalah untuk memperoleh gmbaran yang sistematis dan total dalam melaksanakan proses pembelajaran (Romiszowski,1981). Tujuan dikembangkannya program pembelajaran daring adalah untuk meningkatkan aktivitas pembelajaran mahasiswa dimanapun berada. Selain itu juga diharapkan dapat meningkatkan kompetensi mahasiswa khususnya pada mata kuliah Kurikulum dan Pembelajaran. Pembelajaran daring dipilih sebagai upaya untuk menumbuhkan sikap disiplin, motivasi, dan kemandirian belajar mahasiswa. Selama ini mahasiswa masih sangat tergantung pada kehadiran dosen di dalam kelas. Jika dosen tidak datang, tidak jarang proses pembelajaran tidak terjadi. Program ini diterapkan untuk mengakomodasi permasalahan yang terjadi pada dosen yang memiliki beban mengajar cukup besar. Dengan demikian proses pembelajaran dapat dilaksanakan seefektif dan seefisien mungkin.

Pemberdayaan mahasiswa dalam proses pembelajaran secara berkesinambungan, dapat meningkatkan motivasi dan kemandiriannya dalam belajar. Hal ini disebabkan adanya rangsangan yang diberikan kepada mahasiswa yang menuntut mahasiswa tersebut melakukan aktifitas pembelajaran Miarso (2006) . Hal itu bertujuan agar mahasiswa secara mandiri dapat menginternalisasi pengetahuan, sikap, dan keterampilan tanpa tergantung pada bimbingan langsung dari dosen. Saat akan mengembangkan program pembelajaran daring, khususnya di perguruan tinggi, ada beberapa hal yang harus diperhatikan berkaitan dengan efektivitas pembelajaran mandiri, yaitu mempersiapkan mahasiswa untuk dapat bekerja sesuai dengan kemampuan dan kapasitas yang dimilikinya, mengembangkan alat untuk memperlihatkan peningkatan kompetensi yang dimiliki mahasiswa, menumbuhkan self initation dan self direction dalam belajar, mampu mendorong mahasiswa melakukan self evaluation, serta mampu memotivasi dirinya untuk dapat belajar (Lindvall and Bolvin dalam Joyce and Weil, 2011).

Terdapat beberapa permasalahan yang menjadi hambatan selama keseluruhan proses pengembangan di jalankan, yaitu 1) waktu, waktu pengembangan dan implementasi terlalu sempit, sehingga menyulitkan tim pengembang melakukan ujicoba implementasi program dan 2) jadwal perkuliahan, antara program dan jadwla perkuliahan kurang sinkron. 


\section{SIMPULAN}

Simpulan umum penelitian ini adalah pembelajaran akan efektif jika diketahui kebutuhan belajar mahasiswa. Untuk mengembangkan suatu program perlu diketahui kondisi awal pembelajaran, sehingga perancangan pembelajaran dapat efektif sesuai kebutuhan dan tantangan yang akan dihadapi.

Secara khusus kondisi awal pembelajaran telah sesuai dengan peraturan yang diberlakukan, yaitu pembelajaran dilaksanakan maksimal. Dalam proses pembelajaran belum menggunakan metode maupun media pembelajaran yang variatif. Hal ini berdampak pada antusiasme mahasiswa selama proses pembelajaran berlangsung cenderung tidak stabil, tergantung dari semangat mahasiswa. Hasil belajar mahasiswa juga belum diperoleh hasil yang maksimal sesuai dengan yang distandarkan dalam penilaian pembelajaran.

Pengembangan program pembelajaran daring untuk mata kuliah Kurikulum dan Pembelajaran diperlukan untuk meningkatkan kualitas pembelajaran yang diharapkan dapat meningkatkan kompetensi pedagogik mahasiswa. Untuk itu penggunaan pendekatan sistemik yang berbasis kompetensi menjadi alternatif model rancangan yang digunakan dalam merancang pembelajaran daring. Tujuannya untuk memberikan kemudahan bagi pengembang dalam mengontrol setiap pelaksanaannya.

Program pembelajaran daring, pada prinsipnya dapat menumbuhkan kemandirian belajar mahasiswa. Hal ini ditunjukkan dengan adanya aktifitas pembelajaran mahasiswa tanpa adanya pengawasan dosen secara langsung, serta diharapkan mahasiswa dapat memiliki jejaring yang lebih luas dalam memperoleh pengalaman belajarnya.

\section{Rekomendasi}

Berdasarkan temuan dan simpulan yang diperoleh dalam pembelajaran MKDK Kurikulum dan Pembelajaran bahwa pembelajaran perlu dilakukan peningkatan proses pembelajaran. salah satu rekomendasi sebagai upaya peningkatan pembelajaran yaitu diperlukannya inovasi pembelajaran agar antusiasme mahasiswa dalam pembelajaran dapat lebih meningkat. Inovasi dapat dilakukan melalui penggunaan metode, media, dan evaluasi pembelajaran.

Program pembelajaran daring dapat diterapkan dalam proses pembelajaran pada sistem konvensional dengan mengacu pada prinsip, melihat fasilitas yang telah disediakan oleh pihak lembaga berkaitan dengan teknologi informasi dan komunikasi. Sa- 
Edutech, Tahun 16, Vol.16, No.2, Juni 2017

rana fasilitas internet yang ada di universitas sudah cukup baik dengan adanya jaringan internet yang dapat diakses di lingkungan kampus. Secara teknis, program ini dapat ditindaklanjuti melalui beberapa langkah-langkah sebagai respon dari hasil pengembangan yang telah berjalan, yaitu 1) persiapan dari awal perkuliahan, 2) penyesuaian RPS Mata Kuliah, 3) penyiapan delivery strategy yang lebih sederhana namun tetap variatif, 4) sosialisai penggunaan kelas daring kepada dosen-dosen pengampu MKDK Kurikulum Pembelajaran, 5) desiminasi melalui seminar serta kebijakan khusus MKDK Kurikulum pembelajaran sebagai bentuk implementasi kelas aring terbuka yang lebih luas di lingkungan UPI, dan 6) perancangan system integrasi dan penyesuaian kredit mata kuliah Kurikulum dan Pembelajaran di seluruh LPTK di Indonesia

\section{DAFTAR PUSTAKA}

Alinawati, Muthia dkk. (2009). Studi Implementasi Kurikulum Berbasis Kecakapan Hidup (Life Skills) Pada Jenjang Sekolah Dasar. Bandung. Jurnal Abmas Vol. 9 No.2, Oktober 2009

Baisa, Idi Rathomy. (2010). Pengaruh Penerapan Media Pembelajaran Berbasis Web terhadap Keterampilan Berpikir Kritisdan Kemampuan
Kognitif Siswa Kelas V SD Islam Sabilillah Malang. [Online] Tersedia pada alamat http://karyailmiah.um.ac.id/index.php/ disertasi/article/view/5763 .

Depdiknas. (2005). Peraturan Menteri Pendidikan Nasional No. 74 Tahun 2007 tentang Guru. Jakarta: Depdiknas.

Dhesiana. (2009). Kemandirian dalam Belajar. [Online] Tersedia pada alamat http://

dhesiana.wordpress.com/2009/01/16/ kemandirian-dalam-belajar/. Diunduh pada tanggal 15 desember 2010

Gall \& Borg. (1989). Educational Research An Introduction, Fifth Edition. New York: Longman.

Gufron, Anik. (2007). Pemutakhiran Kurikulum di Perguruan Tinggi. Jurnal Cakrawala Pendidikan. Februari 2007 Tahun XXVI No.1.

Hasbullah.(2009). Perancangan dan Implementasi Model Pembelajaran ELearning untuk Meningkatkan Kualitas Pembelajaran di JPTE FPTK UPI. Bandung.

Hoogveld, Albert W.M.; Paas, Fred; Jochems, Wim M.G; Merriënboer. 
Edutech, Tahun 16, Vol.16, No.2, Juni 2017

(2001). The Effect of a Web-based Training in an Instructional Systems Design Approach on Teachers' Instructional Design Behavior. Journal of PERGAMON. Computers in Human behavior 17, p 363371. Available at www.elsevier.com/locate/ comphumbeh.

Hussin, Husnayati. Bunyarit, Fatimah \& Hussein, Ramlah. (2009). Instructional design and elearning. Examining learners' perspective in Malaysian institutional of higher learning. Jurnal Campus- Wide Insformation System Vol. 26 No. 1, 2009 p 4-19. Emerald Group Publishing Limited.Joyce, Bruce., Weil, Marsha., Calhoun, Emily. (2011). Models of Teaching Eighth Edition. Boston: Pearson Prentice Hall.

Joyce, Bruce., Weil, Marsha., Calhoun, Emily. (2011). Models of Teaching Eighth Edition. Boston: Pearson Prentice Hall.

Lee, Wen-Yu, et al. (2002). Defining Individual Learning Styles for learning Anatomy in a Technologyenhanced Learning Environment. [Online] Tersedia pada alamat http://www.uchsc.edu/sm/chs/ events/vh_conf/pdfs /040.pdf. Diunduh pada tanggal 20 Mei 2009

McNulty, John A; Dauzvardis, Michael F; Espiritu, Baltazar. (2000). Evaluation of Web-based Computeraided Instruction in a Basic Science Course. Journal of Academic Medicine, Vol 75, No.1, p 5965.Moisey, Susan D. Hughes, Judith A. (2008). Supporting The Online Learner. [online] available at http://cde.athabascau.ca/ online_book/pdf/TPOL_chp15. pdf. Diunduh pada tanggal 20 September 2009

Miarso, Yusufhadi, (2006). Menyemai Benih Teknologi Pendidikan, Jakarta : Kencana.

Moisey, Susan D. Hughes, Judith A. (2008). Supporting The Online Learner. [online] available at http://cde.athabascau.ca/ online_book/pdf/TPOL_chp15. pdf. Diunduh pada tanggal 20 September 2009

Ng, Wan. (2008). Self-directed learning with web based sites. How well do student perceptions and thinking match with their teachers?. Journal of Teaching Science: 54,2. Proquest Central 
Oliver, Ron. (2000). Web-based Learning and Generic Skills Development. UniServe Science News Volume 15 March 2000. [Online] Tersedia pada alamat http:// sydney.edu.au/science/ uniserve_science/newsletter/vol15/ oliver.html

P21 Partnership for $21^{\text {st }}$ Century Learning. (2008). $21^{\text {st }}$ Century Skills, Education, and Competitiveness. A Resource and Policy Guide. Partnership for $21^{\text {st }}$ Century Skills

Pruchincki, Maria C; Bennet, Marialice S; Legg, Julie E; Mungal Dennis. (2005). Innovation in Teaching. Development and implementation of a Web-Based Advanced Teaching Experience. American Journal of Pharmaceutical Education, 69, 15; Proquest Central. Romiszowski, A.J. (1981). Designing instructional systems: Decision making in course planning and curriculum design. London and New York: Kogan Page.

Romiszowski, A.J. (1981). Designing instructional systems: Decision making in course planning and curriculum design. London and New York: Kogan Page.
J.D. (2007). Instructional Technology and Media for Learning $9^{\text {th }}$ edition. New Jersey: Pearson Merrill Prentice Hall.

Sudjana, Nana. (1985). Teori Belajar dan pembelajaran. Jakarta: Fakultas Pasca Sarjana IKIP Jakarta.

Sukmadinata, N S, (2001). Pengembangan Kurikulum. Teori dan Praktek. Bandung: Remadja Rosdakarya.

The Partnership for 21st Century Learning. (2015). P21 Framework Definitions. Tersedia pada laman www.p21.org.

Uno, Hamzah B. (2010). Model Pembelajaran Menciptakan Proses Belajar Mengajar yang Kreatif dan Efektif. Jakarta: Bumi Aksara

Zakaria, Masduki. (2007). E-

Learning as Independent Learning Model with Cooperative Approach to Improve Higher Education. [Online] Tersedia pada alamat http:// eprints.uny.ac.id/4590/. Diunduh pada tanggal 30 Juni 2011.

Smaldino, S. E., Lowhter, D. L., Russel, 221 Rancangan Program Pembelajaran Daring Di Perguruan Tinggi: Studi Kasus Pada Mata Kuliah Kurikulum Pembelajaran Di Universitas Pendidikan Indonesia 